\title{
Narratives of Loss and Order and Imaging the Belgian Landscape 1900-1945
}

\author{
Bruno Notteboom \\ Ghent University \\ David Peleman \\ Ghent University
}

Follow this and additional works at: https://docs.lib.purdue.edu/clcweb

0

Part of the Comparative Literature Commons, and the Critical and Cultural Studies Commons

Dedicated to the dissemination of scholarly and professional information, Purdue University Press selects, develops, and distributes quality resources in several key subject areas for which its parent university is famous, including business, technology, health, veterinary medicine, and other selected disciplines in the humanities and sciences.

CLCWeb: Comparative Literature and Culture, the peer-reviewed, full-text, and open-access learned journal in the humanities and social sciences, publishes new scholarship following tenets of the discipline of comparative literature and the field of cultural studies designated as "comparative cultural studies." Publications in the journal are indexed in the Annual Bibliography of English Language and Literature (Chadwyck-Healey), the Arts and Humanities Citation Index (Thomson Reuters ISI), the Humanities Index (Wilson), Humanities International Complete (EBSCO), the International Bibliography of the Modern Language Association of America, and Scopus (Elsevier). The journal is affiliated with the Purdue University Press monograph series of Books in Comparative Cultural Studies. Contact: <clcweb@purdue.edu>

\section{Recommended Citation}

Notteboom, Bruno; and Peleman, David. "Narratives of Loss and Order and Imaging the Belgian Landscape 1900-1945." CLCWeb: Comparative Literature and Culture 14.3 (2012): <https://doi.org/10.7771/1481-4374.2046>

This text has been double-blind peer reviewed by $2+1$ experts in the field.

The above text, published by Purdue University Press (CPurdue University, has been downloaded 579 times as of 11/ 07/19.

This document has been made available through Purdue e-Pubs, a service of the Purdue University Libraries. Please contact epubs@purdue.edu for additional information.

This is an Open Access journal. This means that it uses a funding model that does not charge readers or their institutions for access. Readers may freely read, download, copy, distribute, print, search, or link to the full texts of articles. This journal is covered under the CC BY-NC-ND license. 


\title{
PURDUE
}

UNIVERSITY PRESS <http://www.thepress.purdue.edu>

\section{CLCWeb: Comparative Literature and Culture \\ ISSN 1481-4374 <http://docs.lib.purdue.edu/clcweb> Purdue University Press @Purdue University}

CLCWeb: Comparative Literature and Culture, the peer-reviewed, full-text, and open-access learned journal in the humanities and social sciences, publishes new scholarship following tenets of the discipline of comparative literature and the field of cultural studies designated as "comparative cultural studies." In addition to the publication of articles, the journal publishes review articles of scholarly books and publishes research material in its Library Series. Publications in the journal are indexed in the Annual Bibliography of English Language and Literature (Chadwyck-Healey), the Arts and Humanities Citation Index (Thomson Reuters ISI), the Humanities Index (Wilson), Humanities International Complete (EBSCO), the International Bibliography of the Modern Language Association of America, and Scopus (Elsevier). The journal is affiliated with the Purdue University Press monograph series of Books in Comparative Cultural Studies. Contact: <clcweb@purdue.edu>

\section{Volume 14 Issue 3 (September 2012) Article 11 Bruno Notteboom and David Peleman, "Narratives of Loss and Order and Imaging the Belgian Landscape 1900-1945" <http://docs.lib.purdue.edu/clcweb/vol14/iss3/11>}

\author{
Contents of CLCWeb: Comparative Literature and Culture 14.3 (2012) \\ Thematic Issue New Work on Landscape and Its Narration \\ Ed. Sofie Verraest, Bart Keunen, and Katrien Bollen \\ <http://docs.lib.purdue.edu/clcweb/vol14/iss3/>
}

\begin{abstract}
In their article "Narratives of Loss and Order and Imaging the Belgian Landscape 19001945" Bruno Notteboom and David Peleman analyze a number of publications on landscape, focusing on narratives constructed by means of landscape images published in Belgium. With the work of Jean Massart and Emile Vanderwelde as a point of departure, Notteboom and Peleman discuss popularizing publications in the fields of botany, agricultural education, and tourism, as well as an urban planning. They address the three realms of landscape narratives defined by Matthew Potteiger and Jamie Purinton as story, context/intertext, and discourse. Notteboom and Peleman distinguish three recurrent operations or narrative techniques: framing, sequencing, and juxtaposing whereby their main argument is that in spite of their ideological differences the publications they discuss seek a way of dealing with processes of modernization and with the loss of a traditional way of living defined by a direct relation with the land.
\end{abstract}


Bruno Notteboom and David Peleman,

"Narratives of Loss and Order and Imaging the Belgian Landscape 1900-1945"

CLCWeb: Comparative Literature and Culture 14.3 (2012): <http://docs.lib.purdue.edu/clcweb/vol14/iss3/11>

Thematic Issue New Work on Landscape and Its Narration. Ed. Sofie Verraest, Bart Keunen, and Katrien Bollen

\section{Bruno NOTTEBOOM and David PELEMAN}

\section{Narratives of Loss and Order and Imaging the Belgian Landscape 1900-1945}

In most Western countries, the end of the nineteenth century brought a heightened awareness to landscape. Because of the development of tourism and nature exploration, the interest in landscape issues shifted from a handful of artists and scientists to a broader part of the population. In Belgium, this concern with landscape is related to the rapid change of the landscape under the impact of a number of spatial and socio-economical developments, such as the expansion of a fine-mazed railroad network, the industrialization of the countryside, and a housing policy based on spatial dispersal (see Notteboom, Ouvrons 33-39). Many scholars have noted that the term "landscape" - defined as "a portion of the earth's surface that can be comprehended at a glance" - is used for both the physical landscape and its representation (Jackson Brinckerhoff 8 ). This paper does not focus on the actual transformations of the land itself, but on how these transformations are dealt with in landscape images, and on the way in which images are used in publications to construct narratives on landscape. The focus is on the period 1900-1945, a period not only marked by a rapid transformation of the landscape, but also by a number of narratives on landscape that are developed to deal with this transformation.

Our research on landscape narratives is based on popularizing documents and publications, from didactic atlases to publications by photographical societies to tourist guides and journals published in Belgium. Within the framework of this article, we take the work of biologist Jean Massart (1865-1925) and Belgian statesman Emile Vanderwelde (1866-1938) as a point of reference. As a professor at the Université Libre de Belgique (ULB), Massart is considered to be one of the founders of modern geobotany, the branch of botany that establishes the link with geography and sociology (on Massart's work on biology and sociology, see, e.g., L'Evolution; see also Notteboom, "Een neutraal" 23). Massart developed tools for the popularization of knowledge throughout his career and apart from his scientific atlases he published numerous popularizing books, articles, tourist guides, and similar material. We focus on his series of photographic albums Les Aspects de la végétation en Belgique commissioned by the National Botanical Garden and the Ministry of Agriculture in order to make Massart's scientific research available to an audience beyond scholarship (Massart and Bommert).

In their book Landscape Narratives Matthew Potteiger and Jamie Purinton state that both narrative and landscape can be described as cultural systems of signification, thereby recognizing the importance of context and expanding the notion of text (for example, to images) in the production of meaning. Three particular realms of landscape narratives can be distinguished: "The story realm is the world of the story itself. The emphasis is on the story (event, plot, character, point of view, etc.). However, it is important to see how stories relate to contexts and other texts. The emphasis in the contextual/intertextual realm is on the role of the readers, community, or memory in the making of landscape narratives. The third realm of discourse requires attention to whose story is told and what ideologies or world views are implicit in the telling" (41). We use these three realms as a framework to analyze the work of Massart and his contemporaries: first, we outline and analyze the story on landscape constructed in Les Aspects de la végétation en Belgique, second, we discuss a number of images and texts that reframe Massart's originals, and third, we examine the ideologies at stake (for Massart's images, see Recollecting Landscapes <http://www.recollectinglandscapes.be>).

The narrative in Les Aspects is constructed by means of a systematic sequencing of landscape scenes, represented in a series of didactic plates. At the time, the large-size plates $(30 \mathrm{~cm} \times 40 \mathrm{~cm})$ were considered suitable for instructional purposes in the context of both university and secondary education, in agricultural schools in particular. Massart's aim was to visualize the system of the geobotanical districts (areas in which the geographical condition leads to a specific type of natural vegetation and particular cultivation methods used by farmers). The sequence of landscapes follows a trajectory through Belgium from west to east, from the coast to the German border. The systematic character of the inventory is reinforced by the captions in the margins of the photographs, which indicate the number of the plate in the series, the geo-botanical district, the coordinates of the photographer, the direction of the viewpoint, the date of recording, and a brief description of the 
botanical and agricultural specifics of the landscape. In these captions, Massart explains the relationship between the geo-botanical conditions and the physical appearance of the landscape, for example by drawing attention to the edges of the geo-botanical districts. Sequencing is not only used as a method for the series as a whole, but, in some cases, also within the didactic plate itself. In some of the plates, smaller photographic images are inserted in the margins to show the landscape in the main image at another point in time (for example after the harvest), to zoom in on a detail of the vegetation, or to present the landscape from a different angle.

The narrative of Les Aspects not only unfolds through sequences of interrelated images between or within the plates; in the photographic image itself, too, Massart applies a kind of "narrative densification": most of the landscapes reflect an encompassing and coherent world view (Pinxten, Verschaffel, Van der Woud 345). For example, the photo of the fields in Ruiselede from 1905 portrays the agricultural world as a perfect cycle, with the different links in the chain from producer to consumer: the freshly harvested rye fields, the haystacks, the windmill, and the farms in the distance (see Recollecting Landscapes <http://www.recollectinglandscapes.be>). The caption explains the coherence between the agricultural method and the specific geo-botanical features of the region: the poor, sandy soil demands an intensive cultivation. Only because of the extreme fragmentation of the soil and a system of several harvests a year, the small-scale family farms could survive. In one image, Massart summarizes these aspects of the farmers' lives and work in Ruiselede. Each image in itself as well as the sequence of images show a rural world that is determined by the system of geo-botanical districts - in other words, a world in which the landscape and the way man inhabits and cultivates it is determined by local conditions, such as the nature of the soil.

Although Massart situates his work in a scientific context - he aimed at creating an image of the landscape that was "free of poetical and philosophical deductions" (Nos Arbres iv) - a comparison with contemporary artistic photography sheds light on what his images actually do and do not tell. The pictorialist landscapes, in which all references to industrial society and social unrest were kept out of frame, can be read as reassuring images in the salons of a bourgeoisie that suffered from a fundamental anxiety about the social changes that were on their way (see Mélon 279). Massart's interest in natural and traditional-rural landscapes has to be situated in a different ideology. The didactic plates of Les Aspects served as tools for the emancipation of the lower classes through the popularization of knowledge and several of Massart's "sociobiological" publications demonstrate his sympathy for the political left (see Massart and Vandervelde; Massart, Vanderwelde, Demoor). In addition, the visual language of Massart's pin-point-sharp landscapes is significantly different from the painterly pictorialist mise-en-scène. However, despite the obvious differences in terms of visual language and social context, Massart's landscapes bear a striking resemblance with contemporary photography in the selection of subjects. More specifically, Massart made similar choices about what to leave out of the image frame: the rapid modernization of the countryside. For example, in the photo of Ruiselede, a number of topics are cut off by the frame: the local school where young farmers learned new agricultural techniques that would soon alter the way in which the fields were cultivated, the steam engines that would eventually replace the windmills, and the vicinal railway that allowed farmers to sell their products on the market in the city (see Vanbelleghem 256-58). In 1914, the agrarian cycle and the coherent world image on the photo of Ruiselede had already opened up to influences from outside. Like their pictorialist counterparts, Massart's images show a world that is on the brink of disappearance. Massart's work and pictorialist landscape photography engage in the same act of framing: to demonstrate the coherence and the validity of the systematics of the geo-botanic regions, Massart's scientific reduction of the landscape image coincides with the pictorialists' artistic reduction of the rural world. The publication of Les Aspects de la végétation en Belgique was soon followed by further action to preserve (at least some samples of) the disappearing world. In 1912, one year after the second volume of Les Aspects had appeared, Massart published Pour la protection de la nature en Belgique, which is considered a crucial step in nature preservation in Belgium. In this book, Massart proposes seventy-five nature reserves, categorized according to the geo-botanical districts. A large part of the landscapes portrayed in Les Aspects appeared on this list. In 1914, Massart pleaded in the Royal Commission of Monuments and Sites (Commission Royale des Monuments et des Sites / Koninklijke Commissie voor Monumenten en Landschappen) for the preservation of one or more 
representative rural landscapes for each geo-botanical district, consisting of a site of typical farms with their surrounding fields - in fact, for the creation of a kind of dispersed open-air museum that would be a "real" version of the didactic plates of Les Aspects (see Anonymous). He considered the preservation of these sites as a necessary action to safeguard the knowledge about traditional rural production methods and ways of life, on the verge of disappearance because of the modernization of agriculture.

Many scholars have emphasized that pictorialist photography is based on pastoral scenes. For example, according to Potteiger and Purinton the pastoral topos "is connected with narratives of retreat from the social complexities of the city and a nostalgic return to origins, childhood, and a place apart in harmony with nature" (11). As we have indicated, Massart was involved in all kinds of initiatives to improve the situation of the impoverished rural and urban population, and therefore, his landscapes can hardly be called pastoral in the sense that they would seek a retreat of social reality. However, even if Massart did not subscribe to pictorialist landscape photography's narrative of retreat, his work can be situated within a number of narratives of loss which were present in the early twentieth century. As a reaction to the rapid transformation of countryside and nature, many discourses on landscape from this period comment on the modernization of society and space and thus constitute narratives of the loss of a direct, "natural" relationship between humanity and the land. The creation of narratives by means of landscape images allows us to re-frame our changing relationship to the land, or, as Denis Cosgrove puts it in Social Formation and Symbolic Landscape, "landscape constitutes a discourse through which identifiable social groups historically have framed themselves and their relations with both the land and with other human groups, and this discourse is closely related epistemically and technically to ways of seeing" (xiv). A frequently recurring narrative - and one that is closely related to that of losing a direct relationship to the land - is that of the loss of traditional forms of community. The mythical belief in a transparent and small-scale (mostly agrarian) community that is said to have existed in the past and that is now lost can even be considered a central paradigm in discourses on community in the twentieth century (see Nancy). Although Massart did not express ideas on urban planning issues himself, the socio-biological ideas that he developed led - at least in Vandervelde's writings - to the idea of the "retour à la terre," the urban laborers' return to the countryside (see Vandervelde). The success of the publications on sociobiology - Massart's and Vandervelde's Parasitisme organique et Parasitisme Social - was translated to English by William MacDonald (with a preface by Scottish biologist/sociologist/town planner Patrick Geddes) can be located in a broader "back to nature" movement occurring in the nineteenth century in West European countries, for example in the German Lebensreform movement (see, e.g., Buchholz, Latocha, Peckmann, Wolbert; Just). These narratives of loss and return to nature often are, as Ton Lemaire formulates it, "accompanied by a more or less openly avowed desire for a more original, archaic relationship with nature, in which the alienation between man and nature has not yet taken place. ... The idyllic landscape then functions as a flight and an escape from the split and torn-up state of modern times towards a presupposed harmonious world" (60).

In the following we evaluate this landscape-as-compensation thesis. After his death in 1925, Massart's images were re-used in all kinds of publications on the Belgian landscape. Based on an analysis of the textual and visual narratives created in these sources, we will argue that the function of compensation, or escape, is only one aspect of how landscape images functioned between 1900 and 1945. These images also need to be situated in a search for strategies that allow us to deal with all kinds of modernization processes, such as transformations in agriculture and industrialization. We will argue that landscape imagery in this particular period should be understood not only in relation to a narrative of loss, but to narratives of order and planning as well.

At the end of the nineteenth century, the need for a new narrative on landscape and on the relation between the community and the land was particularly strong in the domain of agriculture. The agricultural crisis of the 1870 s and the 1880 s, caused by the globalization of the agricultural market, marked the end of age-old ways of farming (see Seghers and Van Molle 50-63). In the course of the twentieth century, agriculture was modernized and intensified by means of specialization, mechanization, and artificial fertilizers. Governmental services and corporative organizations such as the Farmers' Union, which guided this transition, were confronted with a twofold task: streamlining the 
agricultural production according to industrial principles and organized on a corporative basis, while preserving the image of a traditional countryside that was centered around the family-oriented farm, the village and the church (see Notteboom, Ouvrons 349-93). By means of educational initiatives (including courses, lectures, model villages and farms, and illustrated journals), farmers' organizations informed the rural population about modern farming while re-enforcing the image of a proud (and Catholic) peasantry whose lifestyles and morals were rooted in tradition.

A publication that can be considered a pre-eminent example of this balancing act is Vander Vaeren's Het Goudboek van de Belgische landbouw (The Goldbook of Belgian Agriculture), published by the Ministry of Agriculture (Ministère d'Agriculture / Ministerie van Landbouw) in 1939. In addition to a text on the Belgian rural economy and the role of agricultural education, the book includes many photographic illustrations of the Belgian agricultural regions. The classification of the agricultural regions more or less follows the geo-botanical districts that Massart had proposed thirty years earlier in Les Aspects de la végétation en Belgique, which had been published by the Ministry of Agriculture as well. Even though it only focuses on agriculture, Het Goudboek displays a striking resemblance with Les Aspects. However, it also adds a new layer of information: Massart's images are placed among more recent images from the collection of the Farmers' Union and the Ministry of Agriculture. The negotiation between modernization - left out of sight by Massart - and tradition is reflected in a clever juxtaposition of the images. In many instances, aspects of the rural world are placed side by side: agro-industrial installations on the left page versus traditional rural landscapes and manual labor on the right page or large-scale corporative festivities organized by farmers' organizations on the left versus age-old solitary farms on the right. Although the technical innovations promoted by the Ministry of Agriculture would eventually cause local differences to be effaced, the book suggests that modernization can be pursued while preserving rural traditions. Instead of an image of a landscape that was radically altered by the modernization of agriculture, the book constructs an image of a countryside where technical innovations have slipped into the existing situation without radically altering it. The book and its layout create a visual narrative that negotiates between modernity and tradition by imposing a visual order on the rural world, creating a balance between what is new and what has always existed.

Another example of a publication in which images by Massart were introduced in a new context is De Kempen, a tourist guide on the Kempen region in the north of Belgium published by the Flemish Tourist Board (VTB: Vlaamse Toeristenbond) in 1922 (see Leurs, De Kempen; Notteboom, Ouvrons 313-29). The guide was part of an ambitious series of tourist guides called Cities and Landscapes. In the interwar era, the VTB published eight volumes, exclusively focusing on Flemish cities and regions. As a propaganda medium for the emerging Flemish political and cultural elite, the VTB used tourism as a tool for the creation of a Flemish identity and the emancipation of Flemish cultural life (Limbourg, Toerisme). In Stan Leurs's De Kempen, the Kempen region is propagated as the pre-eminent Flemish landscape. The guide consists of a number of distinct chapters in which specialists describe the region from several perspectives, such as geography, economical and political history, architecture, and urban and rural planning. The geographical and botanical aspects of the region are illustrated by Massart's photos and the guide includes a map of natural areas to be protected that is based on the map Massart published a decade before in Pour la protection de la nature en Belgique. In addition to Massart's photos, illustrations in the guide include a series of photos that were made by the Antwerpbased photographer Eugeen De Kock and evoke the Kempen as the region has figured in landscape painting since the nineteenth century: a countryside consisting of sandy roads, old farms, and peasants in traditional attire.

Since the end of the nineteenth century, the Kempen region has served as the example of a traditional rural area in which man has always lived in close harmony with nature, far away from the city. For example, in 1922, the Royal Society for the Beauty of Nature and City (KVNS: Koninklijke Vereniging voor Natuur- en Stedenschoon) organized "Onze Kempen" ("Our Kempen"), an exhibition of paintings, photographs - including work by De Kock - folkloristic costumes, and objects from the Kempen region (see Notteboom, "'Onze Kempen"'; Vereniging). However, in contrast with the nostalgic discourse that informed the exhibition, the VTB book is characterized by a more analytic tone. The Kempen region is presented as an object of study for scientific disciplines including 
geography, biology, archaeology, and historical science. Even the interest in folklore is couched in scientific terms: for the VTB, folklore is a specific branch of historical science, institutionalized and systematized by the establishment of a Commission of Folklore (Commissie voor Folklore) in 1926 (see Limbourg 94-131).

Clearly, the guide De Kempen aimed for a specific image of Flanders to become imprinted on the minds of VTB members: one that is largely based on traditional landscapes, architecture, objects, and costumes. At the same time, the book is a kind of inventory of things which belong to the past and VTB called on its members to inventory Flemish monuments and landscapes under the guidance of the commissions of experts in the tourist organization (see De Mont). The idea of an inventory points to a commemorative interest rather than a purely nostalgic discourse. The disappearance of the old world of the Kempen - and the need for consolation - is the reason why this book was written. However, although the change of the Kempen region is considered to be regrettable, it is inevitable and, according to writer Georges Eekhoud, who wrote the introduction to the book, even a form of poetry in itself:

This ambiguity, this hesitation between two systems, this sacrificing of the past to the arrival of a new era contains a poetry that is more moving than the idyll, the pastoral, and even the drama of days long gone. On the eve of their fateful disappearance, those peasants are twice as beautiful, as striking, as soul-stirring! They are the main stake of a decisive battle that is fought between countryside and city. ... As for the Kempen, this time the land will have died before its inhabitants or before those who had selected it as their favorite region. Will the books that best glorify this land provide comfort to those who were forced to leave and mourn the demise of their Motherland? (Eekhoud 22; trans. Katrien Bollen)

Dit dubbelzinnige, die aarzeling tusschen twee stelsels, dit opofferen van het verleden voor de komst van een nieuwen tijd bevat een nog aangrijpender poëzie dan de idylle, de herderszang en zelfs het drama uit vervlogen tijden. Op den vooravond van hun noodlottige verdwijning zijn die boeren dubbel zoo schoon, zoo treffend, zoo ontroerend! Zij zijn den voornaamsten inzet van een beslissende partij die tussen land en stad gespeeld wordt. ... Wat de Kempen betreft, ditmaal zal het land eerder gestorven zijn dan zijn bewoners of eerder dan hen die het tot hun lievelingsstreek verkozen hadden. Zullen de boeken waarin dit land het best verheerlijkt werd die verdrevenen troosten over den ondergang van hun Moederland? (Eekhoud 22)

Eekhoud near-explicitly announces a new narrative: the advent of new times, a narrative that replaces older ones such as "the idyll, the pastoral, and even the drama of days long gone." While the book pleads for the preservation of a number of natural areas - with Massart's map as a guideline - the industrialization of the Kempen region is not questioned. The economic future of the region, based on the local mining industry, was an important factor in the emancipation of Flanders. Lieven Gevaert, founder of Gevaert photo company, was also a member of the VTB board and one of the most influential promoters of Flemish economic life. In De Kempen, the idea of a flourishing industry is represented rather literally by a drawing of "the twentieth-century industrial tree": the myriad of modern products (the branches) all spring from one trunk, rooted in the underground charcoal layers. This image of the Kempen as an industrial region where industry springs "naturally" from the soil adds a new layer of identity to the area.

In order to find a balance between the different aspects of the Kempen region, in De Kempen photography is used as a tool to create a visual ordering, an image of the region as three distinct realms that make up the identity of the region and its inhabitants: that of virgin nature (Massart's photos), the traditional countryside (De Kock's photos), and new industry (photos of the mining installations and factories). In the discourse of the VTB, this visual ordering was gradually complemented by its spatial counterpart. In several articles in Toerisme, the members' journal of the $V T B$, the principles of urban planning were introduced. One of the contributors to the journal was architect Huib Hoste, who collaborated with Le Corbusier in the competition for the development of the Antwerp Left Bank in 1933 (see Commers, Lombaerde, Commers). In Toerisme, Hoste pleads for a spatial development based on zones of dwelling, working, and recreation, according to the principles of modern planning (see Hoste). In addition to commissions for folklore, monuments, and nature, the VTB created one for traffic, showing great interest in the developments in spatial planning as well as modern road infrastructure in Germany (see Limbourg 115).

The combination of a visual and a spatial ordering became the focal point of a number of urban planning documents that were developed later on. During World War II, architects Huib Hoste and 
Leurs - who edited the tourist guide series Cities and Landscapes for the VTB - became part of the General Commissioner's Office for the Reconstruction of the Country (CGLW: Commissariaat-Generaal voor's Lands Wederopbouw). The CGLW incorporated the Belgian modernist movement and, more specifically, the Flemish-militant cultural elite that had developed during the interbellum. According to Pieter Uyttenhove, its "naïve rationality" made the modern movement the perfect ally for the German occupier, even if the CGLW was not involved in politics as such (466). The CGLW developed the prewar ideas on functional zoning into a regional plan. Urban planners Raphaël Verwilghen and Renaat Soetewey published the first regional plan which targeted the province of Limburg in 1942. Its objective was determined by existing and future locations for mining and industry. The central element of the plan is a continuous industrial ribbon development along the Albert Canal, paralleled by infrastructure (railways and highways), and a linear strip for housing. The idea of a ribbon development along the Albert Canal had already been proposed by several Belgian modernists in the 1930s, for example by Renaat Braem, who was inspired by Soviet projects for linear cities in the 1920s (see Strauven 25-28). The CGLW plan for Limburg, however, adopted a new perspective to this idea: they paid equal attention to the landscape. The province of Limburg was subdivided into three zones: natural landscapes, agricultural landscapes, and nature reserves. The location of these reserves followed Massart's proposition in Pour la protection de la nature en Belgique, although a large-scale nature reserve parallel to the German border was added.

Although the regional plan was a document for urban planners and therefore not destined for the audience at large, its argument is very comprehensibly constructed by means of a clever juxtaposition of images and text. While the lay-out of the industrial city is mainly legitimized by a survey with maps and statistics, the subdivision of the landscape is illustrated with a series of photos, most of which came from the VTB archive. These photos are placed in a certain order, and can be read as a narrative on man's gradual transformation of the landscape. A first series of photos depicts "the primeval landscape of the Kempen, as it is since centuries," a next series (a sand road and primitive farms) shows "the first contact of man with the primeval landscapes. Road and dwelling are part of the landscape," and the last one represents the man-made agricultural landscapes in the south of the province. The zoning plan and the photographical images in the document allow the CGLW to combine two sides of modern spatial planning. The map projects the order of a new and rationally organized industrial city onto the old landscape of the photos, a landscape that was shaped by nature and tradition. The visual language of the regional plan for Limburg allowed to reframe the idea of functional zoning - a concept that, to a large extent, had been developed in the interwar era in leftist modernist circles - in a blood-and-soil rhetoric that is further developed in the text:

That is exactly where we find the purest landscape beauty that still exists in Flanders. That is a valuable possession: soil and race are the two constitutive elements of a nation. Yet, whereas the race can transform itself and even degenerate due to the arrival of foreign elements, the soil, by contrast, continues to exert a constant, steady influence. From first to last, it is the origin of a nation's most pronounced characteristics, of that which, in the cultural realm, has been called the "constants." ... What is to be rescued here is very dear to us. What can be rescued here is part of the very soul of our mother country. (Trans. Katrien Bollen)

Daar precies vinden wij het zuiverste landschapsschoon dat er in Vlaanderen nog bestaat. Dat is een kostbaar bezit: bodem en ras zijn de twee constitutieve elementen van een volk. Doch waar het ras zich kan omvormen en zelfs ontaarden ten gevolge van toevoer van uitheemsche elementen, blijft de bodem daarentegen een zelfden, bestendigen invloed uitoefenen. Hij is in eerste en laatste instantie de oorsprong van de meest uitgesproken karaktertrekken van een volk, van datgene wat men op kultureel gebied, de "constanten" heeft genoemd. ... Wat hier te redden is, ligt ons nauw aan het hart. Wat hier gered kan worden hoort tot de ziel zelve van ons vaderland. (Verwilghen and Soetewey 7-8)

In conclusion, in our analysis we address the three realms of landscape narratives that are defined by Potteiger and Purinton and pertain to the story, context/intertext, and discourse. In publications ranging from Massart's early-twentieth-century albums to the planning documents produced during World War II by the CGLW, we can distinguish a number of recurrent operations that are carried out on landscape images. A first operation is the act of framing: the frame determines which information is included and excluded. For example, in the case of Massart, additional photographical material allows to see what the photographer left out: signs of modernization that did not fit in with the image of a self-contained agrarian cycle. A second operation is sequencing. As a story is related to time and 
movement, two or more events (or images) can make up a narrative sequence (Potteiger and Purinton 109-34). Although Massart crisscrossed the country by train, the sequencing of the images in Les Aspects de la vegetation en Belgique evokes a gradual motion from one geo-botanical district to another. In addition, the sequence of landscape images in De planologische ordening van Limburg suggests a gradual movement through the landscape, illustrating the different kinds of relations between man and the soil. A third operation is the juxtaposition of images and text, which allows intertextual meanings to appear: by placing images of modern (agro)industry next to images of traditional landscapes and farms, De Kempen and Het Goudboek seem to create an equilibrium between the rural past and the industrial future. In the publications under consideration, different ideologies are at stake, ranging from the ambition to popularize knowledge on biology and geography, over the emancipation of the Flemish people, to a blood-and-soil ideology. However, these publications have in common that they seek a way to deal with processes of modernization and with the loss of a traditional way of living defined by a direct relation with the land. We have argued that landscape images did not only function as a compensation for this loss, but also as a vocabulary to create a new story on an encompassing planning of the territory in which everything has its place: a narrative of loss was gradually replaced by a narrative of order and planning. In a world where oppositions such as city/countryside and agriculture/industry were increasingly blurred, these publications created a new visual order: a world in which both the old and the new would have its place. It was the ambition of urban planning to translate this visual order into a spatial order.

Note: The above article is based on and with new research from Notteboom, Bruno. "Ouvrons les yeux." Stedenbouw en beeldvorming van het landschap in België 1890-1940 ("Ouvrons les yeux." Urban Planning and Landscape Iconography in Belgium 1890-1940"). Ph.D. Diss. Gent: Ghent U, 2009.

\section{Works Cited}

Anonymous. "Section des Sites. Séances des 20 juin et 22 août 1914." Bulletin des Commissions royales d'Art et d'Archéologie (1914): 126-35.

Buchholz, Kai, Rita Latocha, Hilke Peckmann, and Klaus Wolbert, eds. Lebensreform: Entwürfe zur Neugestaltung von Leben und Kunst um 1900. Darmstadt: Häusser, 2001.

Commers, Ronald, Piet Lombaerde, and Frank Commers. Le Corbusier en de Linkeroever te Antwerpen. Antwerp: Stad Antwerpen en Hoger architectuurinstituut van het Rijk, 1987.

Cosgrove, Denis E. Social Formation and Symbolic Landscape. Madison: U of Wisconsin P, 1998.

De Mont, Paul. "Twee folkloristische Enkwesten. Oproep tot de leden van den VI. Toeristenbond." Toerisme (1928): 63-64.

Eekhoud, Georges. "Inleiding. A. De Kempen van onze schrijvers en kunstenaars." Steden en Landschappen I: De Kempen. Ed. Stan Leurs. Antwerp: De Sikkel, 1922. 5-23.

Hoste, Huib. "Stedenbouw en verkeer." Toerisme (1932): 517-21.

Jackson Brinckerhoff, John. "The Word Itself." Discovering the Vernacular Landscape. New Haven: Yale UP, 1984. 3-8.

Just, Adolf. The True Natural Method of Healing and Living and the True Salvation of the Soul, Paradise Regained. Trans. Benedict Lust. New York: Benedict Lust, 1904.

Lemaire, Ton. "Een wijsgerige wandeling door het landschap." Landschap in meervoud: Perspectieven op het Nederlandse landschap in de 20ste/21ste eeuw. Ed. Jan Kolen and Ton Lemaire. Utrecht: Van Arkel, 1999. 57-70.

Leurs, Stan, ed. Steden en Landschappen I: De Kempen. Antwerp: De Sikkel, 1922.

Limbourg, Marleen. Toerisme en politiek. De Vlaamse Toeristenbond (V.T.B.). MA thesis. Brussels: Vrije U Brussels, 1987.

Massart, Jean. Nos Arbres. Brussels: Lamertin, 1911.

Massart, Jean. Pour la protection de la nature en Belgique. Brussels: Lamertin, 1912.

Massart, Jean, and Charles Bommer. Les Aspects de la végétation en Belgique. Les Districts littoraux et alluviaux. Brussels: Jardin Botanique de l'Etat / Ministère de l'Intérieur et de l'Agriculture, 1908.

Massart, Jean, and Charles Bommert. Les Aspects de la végétation en Belgique. Les Districts flandrien et campinien. Brussels: Jardin Botanique de l'Etat / Ministère de I'Intérieur et de l'Agriculture, 1912.

Massart, Jean, and Emile Vandervelde. Parasitism: Organic and Social. Trans. William MacDonald. London: Swan Sonnenschein, 1895.

Massart, Jean, and Emile Vandervelde. Parasitisme organique et parasitisme social. Paris: Schleicher, 1893.

Massart, Jean, Emile Vanderwelde, and Jean Demoor. L'Evolution régressive en biologie et en sociologie. Paris: Félix Alcan, 1897.

Mélon, Marc-Emmanuel. "De maatschappelijke dimensie van het picturalisme." Pour une histoire de la photographie en Belgique. Essais critiques - Répertoire des photographes depuis 1839. Ed. Georges Vercheval. Charleroi: Musée de la Photographie, 1993. 278-84.

Nancy, Jean-Luc. The Inoperative Community. Ed. Peter Connor. Trans. Peter Connor, Lisa Garbus, Michael Holland, and Simona Sawhney. Minneapolis: U of Minnesota P, 1998. 
Bruno Notteboom and David Peleman,

"Narratives of Loss and Order and Imaging the Belgian Landscape 1900-1945"

page 9 of 9

CLCWeb: Comparative Literature and Culture 14.3 (2012): <http://docs.lib.purdue.edu/clcweb/vol14/iss3/11>

Thematic Issue New Work on Landscape and Its Narration. Ed. Sofie Verraest, Bart Keunen, and Katrien Bollen

Notteboom, Bruno. "Een neutraal beeld bestaat niet. De fotografie van Jean Massart." Recollecting landscapes. Herfotografie, geheugen en transformatie 1904-1980-2004. Ed. Pieter Uyttenhove. Ghent: A\&S, 2006. 23-37.

Notteboom, Bruno. "'Onze Kempen.' Modellen voor stad en landschap." Citygraphy\#01. Ed. Dirk Lauwaert. Brussels: Efemera, 2007. 78-95.

Notteboom, Bruno. "Ouvrons les yeux!" Stedenbouw en beeldvorming van het landschap in België 1890-1940. Ph.D. Diss. Gent: Ghent U, 2009.

Pinxten, Rik, Bart Verschaffel, and Auke Van der Woud. "Beeldcultuur en antropologie." Recollecting Landscapes / Herfotografie, geheugen en transformatie 1904-1980-2004. Ed. Pieter Uyttenhove. Ghent: A\&S, 2006. 34254.

Potteiger, Matthew, and Jamie Purinton. Landscape Narratives: Design Practices for Telling Stories. New York: Johan Wiley \& Sons, 1998.

Recollecting Landscapes. recollectinglandscapes.be (2012): <http://www.recollectinglandscapes.be>.

Seghers, Yves, and Leen Van Molle. Leven van het land. Boeren in België 1750-2000. Leuven: Davidsfonds, 2004.

Strauven, Francis. Renaat Braem. De dialectische avonturen van een Vlaams functionalist. Brussels: AAM, 1983.

Uyttenhove, Pieter. "Architectuur, stedebouw en planologie tijdens de Duitse bezetting. De moderne beweging en het Commissariaat-Generaal voor 's Lands Wederopbouw (1940-1944)." Belgisch Tijdschrift voor Nieuwste Geschiedenis 3-4 (1989): 465-510.

Vanbelleghem, Dries. "Ruiselede. Van boerenstiel naar agro-economie." Recollecting landscapes. Herfotografie, geheugen en transformatie 1904-1980-2004. Ed. Pieter Uyttenhove. Ghent: A\&S/books, 2006: 252-271.

Vander Vaeren, M.J. Het Goudboek van den Belgischen Landbouw / Le Livre d'Or de I'Agriculture Belge. Brussels: Thill, 1939.

Vandervelde, Emile. L'Exode rural et le retour aux champs. Paris: Félix Alcan, 1903.

Vereeniging tot Behoud van Natuur- en Stedenschoon. Onze Kempen. Tentoonstelling en voordrachten. Antwerp: Vereeniging tot Behoud van Natuur- en Stedenschoon, 1922.

Verwilghen, Raphaël, and Renaat Soetewey. De planologische ordening van Limburg. Antwerp: Standaard, 1942.

Author's profile: Bruno Notteboom <http://www.architectuur.ugent.be/vakgroep/medewerkers/bruno-

notteboom/> teaches theory and history of urban planning at Ghent University and landscape urbanism at Sint-

Lucas School of Architecture Ghent. His fields of interest in research include the iconography of landscape and city in urban planning and related disciplines since the nineteenth century. Notteboom's publications include articles in Architectural Research Quarterly, Journal of Architecture, and Oase. E-mail: <bruno.notteboom@ugent.be>

Author's profile: David Peleman <http://www.architectuur.ugent.be/vakgroep/medewerkers/david-peleman/> teaches architectural design and urban design at Ghent University. His fields of interest in research include theory and history of infrastructure, and urban planning. Peleman's publications include articles published in $A+B e l g i a n$ Architectural Review, Journal of Architecture, and Landscape Research. E-mail: <david.peleman@ugent.be> 